\title{
Metabolism of sitosterol by a Pseudomonas species
}

\author{
Shashi B. MAHATO, Sukdev BANERJEE, Atreyee MUKHERJEE and Ranjit KUMAR \\ Indian Institute of Experimental Medicine, 4 Raja S. C. Mullik Road, Calcutta 700 032, India
}

(Received 12 January 1981/Accepted 27 February 1981)

\begin{abstract}
Fermentation of sitosterol by a Pseudomonas species (SK-25) resulted in the formation of 5 -stigmastene-3 $\beta, 7 \alpha$-diol; $5,6 \alpha$-epoxy-5 $\alpha$-stigmastan-3 $\beta$-ol; $5,6 \beta$-epoxy- $5 \beta$-stigmastan- $3 \beta$-ol and $5 \alpha$-stigmastan-3 $\beta, 5,6 \beta$-triol. The metabolites were characterized by a variety of conventional chemical and spectrometric techniques.
\end{abstract}

Sitoserol occurs widely in the plant kingdom along with other phytosterols, e.g. stigmasterol and campesterol. Its major sources are cottonseed oil, til oil and sugarcane wax (Asolkar \& Chadha, 1979). Large quantities of sitoserol accumulate during the isolation of stigmasterol from soya bean (Charney \& Herzog, 1967). Its availability on a large scale has evoked interest in its use in steroid-drug synthesis. However, the degradation of its saturated $\mathrm{C}-17$ side chain is a formidable task. Chemical degradation is not economical and some microbiological processes (Sih \& Wang, 1965; Nagasawa et al., 1970; Marshek et al., 1972; Martin \& Wagner, 1976; Knight \& Worcha, 1977) for oxidizing and cleaving the side chain have been reported. During our screening programme for isolation of microorganisms capable of cleaving the side chain of sitosterol we isolated a Pseudomonas species which could use sitosterol as a sole source of carbon. The Pseudomonas species was found to be incapable of cleaving the side chain, but produced interesting metabolites which are reported in this comminication.

\section{Materials and methods}

\section{Culture method}

Pseudomonas species (SK-25) was isolated from soil by enrichment culture with sitoserol as a sole source of carbon. This was cultivated in flasks containing sterilized modified Davis \& Mingioli (1950) medium [composition (\% w/v): glucose, 0.1; $\mathrm{K}_{2} \mathrm{HPO}_{4}, 0.7 ; \mathrm{KH}_{2} \mathrm{PO}_{4}, 0.3 ;\left(\mathrm{NH}_{4}\right)_{2} \mathrm{SO}_{4}, 0.1$; $\mathrm{MgSO}_{4}, 0.01$; trace elements $0.1 \mathrm{ml}, \mathrm{pH} 7.0$ ]. To each Erlenmeyer flask $(500 \mathrm{ml})$ containing $100 \mathrm{ml}$ of sterile medium $20 \mathrm{mg}$ of crystalline sitosterol was added and the flasks were inoculated with a cell suspension obtained from $18 \mathrm{~h}$-old culture main-

Abbreviation used: h.p.l.c., high-performance liquid chromatography. tained on nutrient agar slant. The volume of inoculum added to each flask was $1 \mathrm{ml}$, containing about $2 \times 10^{6}$ cells. A batch of 15 flasks thus inoculated was incubated on a rotary shaker $(220$ rev. $/ \mathrm{min}$ ) at $35^{\circ} \mathrm{C}$ for 5 days. To exclude the possibility of auto-oxidation a control was designed wherein the Pseudomonas species was cultured in $0.1 \%$ glucose for 5 days and then heat-sterilized, and this mixture was incubated with sitosterol.

\section{Extraction and isolation of transformed products}

After transformation the contents of the flasks were collected and extracted with chloroform. The extract was washed with water and dried over anhydrous $\mathrm{Na}_{2} \mathrm{SO}_{4}$. Evaporation of the solvent gave a semi-solid residue $(220 \mathrm{mg})$. The residue obtained was chromatographed on a column of basic alumina (4g), elution being successively with benzene/ chloroform $(1: 1 \mathrm{v} / \mathrm{v})$, chloroform and chloroform/ methanol $(19: 1 \mathrm{v} / \mathrm{v})$. Thus unconverted sitosterol, metabolite $1(9 \mathrm{mg})$, a mixture of metabolites 2 and 3 $(3.5 \mathrm{mg})$ and metabolite $4(6 \mathrm{mg})$ were isolated. None of the metabolites was isolated from the control.

\section{Analytical methods}

T.l.c. was carried out on silica gel G (B.D.H.) using chloroform/methanol $(96: 4 \mathrm{v} / \mathrm{v})$ as solvent. Optical rotations were measured in chloroform on a Perkin-Elmer automatic polarimeter. I.r. spectra were recorded in Nujol mulls on a Perkin-Elmer model 177 instrument. Mass spectra were determined on a MS 50-A.E.I. spectrometer at an ionizing potential of $70 \mathrm{eV} .{ }^{1} \mathrm{H}$ n.m.r. spectra were recorded at $250 \mathrm{MHz}$ in $\mathrm{C}^{2} \mathrm{HCl}_{3}$ with tetramethylsilane as reference compound. Melting points were obtained in open capillary tubes in a sulphuric-acid bath and are uncorrected. H.p.l.c. was carried out with a Water Associates model 6000A pump, U6K injector, model 440 absorbance detector with a fixed wavelength of $254 \mathrm{~nm}$ and $R 401$ differential refractometer connected to an Omniscribe recorder. 
The chromatograph contained a Waters Associates $30 \mathrm{~cm} \times 3.9 \mathrm{~mm}$ internal diam. stainless steel column packed with a $\mu$ Porasil microparticulate $(10 \mu \mathrm{m})$ silica gel column. The mobile phase was light petroleum/isopropanol $(12: 1 \mathrm{v} / \mathrm{v})$, flow rate $1 \mathrm{ml} /$ min; the pressure was 125 p.s.i.; the temperature was $20^{\circ} \mathrm{C}$; the attenuation $8 \times$ and the recorder chart speed $1 \mathrm{~cm} / \mathrm{min}$. A $20 \mu \mathrm{l}$ volume of the sample solution $(1 \mathrm{mg} / \mathrm{ml})$ was injected into the chromatograph with a $25 \mu \mathrm{l}$ Hamilton syringe.

\section{Results and discussion}

Metabolite $1, \mathrm{C}_{29} \mathrm{H}_{50} \mathrm{O}_{2}\left(M^{+} 430\right)$, m.p. 211$212^{\circ} \mathrm{C},[\alpha]_{\mathrm{D}}^{25}-72^{\circ}$ (c 0.46 in chloroform) gave a deep blue colour with $\mathrm{SbCl}_{3}$ (in chloroform) indicating it to be a 7-hydroxy derivative of sitosterol (I) (Heilbron et al., 1936; Haslewood, 1942). The compound was finally characterized as 5-stigmastene-3 $\beta, 7 \alpha$-diol (II) by direct comparison with an authentic sample (Mahato \& Banerjee, 1980). The mixture of metabolites 2 and 3 could not be separated by column chromatography or preparative t.l.c. However, this identities as 5,6a-epoxy$5 \alpha$-stigmastan- $3 \beta$-ol (III) and 5,6 $\beta$-epoxy- $5 \beta$-stigmastan-3 $\beta$-ol (IV) were confirmed by direct comparison by h.p.l.c. with authentic samples syntheszied from sitosterol (Aringer \& Eneroth, 1974). The identities were further confirmed by t.l.c. of the 3 -acetates of III and IV with authentic samples. The ratio of III and IV, as determined by h.p.l.c. was found to be $10: 13$.

Metabolite 4, $\mathrm{C}_{29} \mathrm{H}_{52} \mathrm{O}_{3}$, m.p. $248-250^{\circ} \mathrm{C},[\alpha]_{\mathrm{D}}^{25}-$ $-2^{\circ}$ (c 0.42 in chloroform) did not show any olefinic, carbonyl or epoxide absorption in its i.r. spectrum.
Its mass spectrum showed peaks at $m / e$ (rel.int.) 448 $\left(M^{+}, 7\right), 430\left(M^{+}-\mathrm{H}_{2} \mathrm{O}, 100\right), 412\left(M^{+}-2 \mathrm{H}_{2} \mathrm{O}, 81\right)$, $397\left(M^{+}-2 \mathrm{H}_{2} \mathrm{O}-\mathrm{CH}_{3}, 23\right), 394\left(M^{+}-3 \mathrm{H}_{2} \mathrm{O}, 7\right)$ $383\left(M^{+}-2 \mathrm{H}_{2} \mathrm{O}-\mathrm{C}_{2} \mathrm{H}_{5}, 8.7\right), 379,\left(M^{+}-3 \mathrm{H}_{2} \mathrm{O}-\right.$ $\left.\mathrm{CH}_{3}, 7\right), 376$ (fragment ion $\left.a, 10\right), 359(a-\mathrm{OH}$, 11.6), 331 (10), $290 \quad\left(M^{+}\right.$-side chain $-\mathrm{OH}$, 16), 262 (15.5), $247\left(M^{+}\right.$- side chain $-42-\mathrm{H}_{2} \mathrm{O}$, 46.5), $244(45), 230(39)$ and $211\left(M^{+}\right.$- side chain $\left.-42-3 \mathrm{H}_{2} \mathrm{O}, 20\right)$. The mass-fragmentation pattern, particularly the formation of ion $a$, is characteristic of a 5-hydroxysteroid (Rotman et al., 1973). The formation of ion $a$ by the primary process directly from the molecular ion is supported by metastable transition. This is quite in conformity with the reported observations (Rotman et al., 1973). Moreover, according to these authors, the presence of substituents at C-6 suppresses the formation of ion $a$ and in a few cases ions $a$ were not formed. We found that for this triol ion $a$ was formed with significant intensity $(10 \%$ of the base peak). The ${ }^{1} \mathbf{H}$ n.m.r. spectrum showed quaternary methyl signals at $\delta 0.70$ (18-methyl) and $\delta 1.2$ (19-methyl), a broad singlet at $\delta 3.55$ assignable to $6 \alpha-\mathrm{H}$ and a multiplet at $\delta 4.1$ ascribable to $3 \alpha-\mathrm{H}$. The downfield shift of the axial proton at C-3 is attributed to the interaction with the $\alpha$ (axial) hydroxy group at C-5. Consequently, the product was characterized as $5 \alpha$-stigmastan- $3 \beta, 5,6 \beta$-triol (V). The identity of the triol was finally confirmed by direct comparison with an authentic sample synthesized from sitosterol (Desmane \& Dev, 1971). The enzymic formation of the metabolites is rationalized in Scheme 1. The diol (II) is presumably formed by direct oxygenation at C-7 of sitosterol (I) as is usually the case with microbial hydroxylation processes. It may reasonably be visualized that the

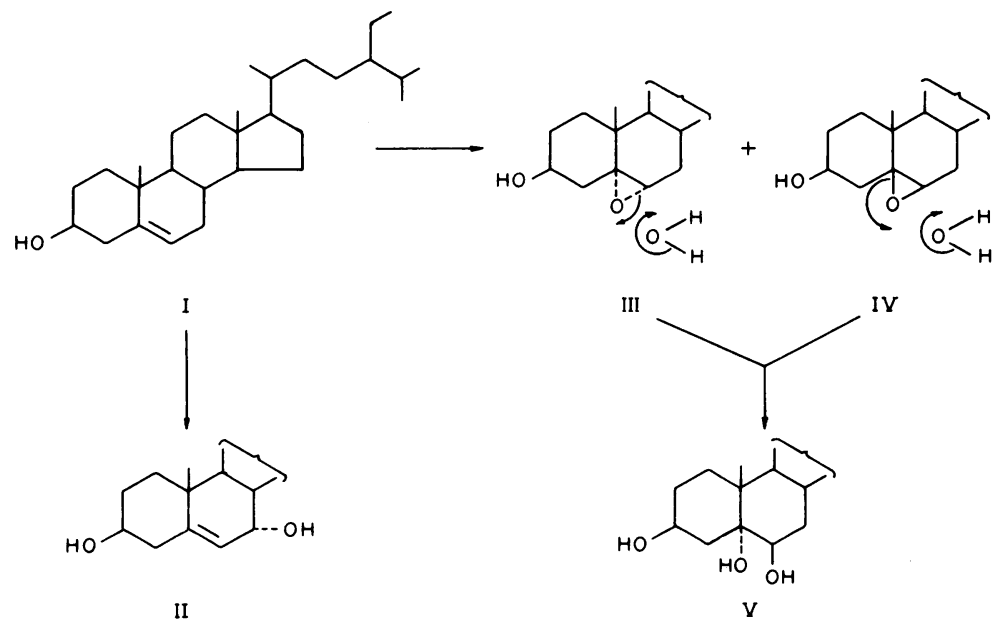

Scheme 1. Structure and mechanism of formation of metabolites of sitosterol 
triol (V) is formed via the epoxides (III) and (IV). Although reported for a few other micro-organisms, epoxidation of a double bond followed by hydrolysis to alcohols has not so far been encountered in studies with Pseudomonas. Chemical epoxidation of the 5,6 double bond of sitosterol with monoperphthalic acid leads to $\alpha$ - and $\beta$-epoxides in the ratio 9:1 (Aringer \& Eneroth, 1974). In the present enzymic epoxidation the $\alpha$ - and $\beta$-epoxides were formed, as already mentioned, in the ratio $10: 13$. The enzymic hydrolysis of epoxides leading to glycols with diaxial opening was first reported by Camerino \& Sciaky (1959). The reaction is reminiscent of a normal acid-catalysed opening of an oxide with water acting as the nucleophile. This enzymic opening of epoxides also follow the principles of conformational analysis that every steroid epoxide should yield a unique product of ring opening, with the epoxide oxygen affording an axial hydroxy group corresponding to the configuration of the epoxide, and the entering nucleophile becoming axially bonded at the other carbon atom (Kirk \& Hartshorn, 1968).

We thank Prof. B. K. Bachhawat, Director of this Institute, for encouragement and Dr. B. C. Das, GifSur-Yvette, France for his assistance concerning the ${ }^{1} \mathrm{H}$ n.m.r. and mass spectra. $\AA$. M. thanks the Director for a Junior Research Fellowship.

\section{References}

Aringer, L. \& Eneroth, P. (1974) J. Lipid Res. 15, 389-398

Asolkar, L. V. \& Chadha, Y. R. (1979) Diosgenin and Other Steroid Drug Precursors, Publication and Information Directorate, New Delhi

Camerino, B. \& Sciaky, R. (1959) Gazz. Chim. Ital. 89, 654-662

Charney, W. \& Herzog, H. L. (1967) Microbial Transformation of Steroids, Academic Press, New York

Davis, B. D. \& Mingioli, E. S. (1950) J. Bacteriol. 60, 17-28

Desmane, S. S. \& Dev. S. (1971) Tetrahedron 27, 1109-1118

Haslewood, G. A. D. (1942) Biochem. J. 36, 389-391

Heilbron, I. M., Barr, T., Parry, E. G. \& Spring, F. S. (1936) J. Chem. Soc. 1437-1440

Kirk, D. N. \& Hartshorn, M. P. (1968) Steroid Reaction Mechanisms, pp. 112-113, Elsevier, New York

Knight, J. C. \& Worcha, M. G. (1977) U.S. Patent $4,042,459$

Mahato, S. B. \& Banerjee, S. (1980) Experientia 36, 515-516

Marshek, W. J., Kraychy, S. \& Muir, R. D. (1972) Appl. Microbiol. 23, 72-77

Martin, C. K. A. \& Wagner, F. (1976) Eur. J. Appl. Microbiol. 2, 243-255

Nagasawa, M., Watanabe, N., Hashiba, H., Tamura, G. \& Arima, K. (1970) Agric. Biol. Chem. 34, 798-800

Rotman, A., Mandelbaum, A. \& Mazur, Y. (1973) Tetrahedron 29, 1303-1309

Sih, C. J. \& Wang, K. C. (1965) J. Am. Chem. Soc. 87, $1387-1388$ 